\title{
Improving the Ability to Classify Animals Based on the Type of Food in Science Studies with STAD Cooperative Method
}

\author{
S. Nurhayati, Rusijono, M Jacky \\ Universitas Negeri Surabaya \\ Surabaya, Indonesia \\ siti.zaidan@gmail.com
}

\begin{abstract}
The purpose of this study was to improve the ability to classify animals based on the type of food in science subjects through the Cooperative Student Teams Achievement Division (STAD) method of fourth grade students at Kedungrejo Elementary School. This research was conducted through several stages, namely: 1) Planning Phase, 2) Implementation Phase, 3) Observation Phase (Observation), and 4) Reflection. The implementation of this learning improvement resulted in an increase in student learning outcomes, which initially had a very low level of student understanding reaching only 32.3\%. Then Classroom Action Research was carried out in the class starting from cycle I with an increase in the percentage of students who achieved the score to $64.5 \%$. However, the achievement was considered unsatisfying, thus, cycle II was conducted. After improvements in the second cycle, the percentage of students achieving the score reached $90.3 \%$. This percentage is considered sufficient to represent the completeness of student learning. In addition to the significant improvement in abilities, it turns out that the activeness of students in the learning process with this STAD Cooperative method also increases.
\end{abstract}

Keywords - STAD Method, Improving Ability

\section{INTRODUCTION}

According to Muslimin, cooperative learning is a learning approach that prioritizes collaboration between students in groups to achieve learning goals. Meanwhile according to Wina, the group learning model is a series of learning activities carried out by students in certain groups to achieve the goals that have been formulated. There are four important elements in cooperative learning strategies, namely the presence of participants in the group, the existence of group rules, the learning efforts of each group member, and the goals to be achieved.

While according to Anita (2007: 2), the cooperative learning model is a learning model that prioritizes the existence of groups and emphasizes cooperation. The purpose of cooperative learning models is that students' academic learning outcomes increase and students can receive a variety of diversity from their friends and develop social skills.

According to Muslimin (in Kamdi, 2009: 1) are: 1) Each group member (student) is responsible for everything done in his group, 2) Each group member (student) must know that all group members have the same goal, 3 ) Each group member (student) must share the same tasks and responsibilities among the members of the group, 4) Each group member (student) will be evaluated, 5) Each group member (student) shares leadership and needs skills to learn together during the learning process , 6) Each group member (student) will be asked to account individually for the material handled in the cooperative group.

According to Krismanto, cooperative learning is a learning model that prioritizes cooperation among students to achieve learning goals. Cooperative learning models have the following characteristics: 1) to complete learning material, students learn in groups cooperatively, 2) groups are formed from students who have high, medium and low abilities, 3) if the class consists of students from several different races, tribes, cultures, each group consists of those differences, and 4) awards are preferred to group work than individuals.

\section{STAD Cooperative Learning}

Reasons in the discussion of STAD cooperative learning for STAD cooperative learning is the simplest of cooperative learning, in addition, can be used to provide understanding of the concept of a difficult material to students where the material has been prepared by the teacher through worksheets or other learning tools. The STAD component according to Slavin (in Kamdi, 2009: 3) is as follows: 1) Class presentation. Class presentations in STAD are different from the usual teaching methods. Each group presented the results of their group discussion. Students must really pay attention to this presentation because in the presentation there is material that can help to do the quiz that is held after learning. 2) Learning in teams. Students are divided into several groups, each group consists of 4-5 people where they do the assignments. If there are difficulties students who feel able to help students who are in trouble. 3) Individual tests. After the learning is complete there is an individual test (quiz). 4) Individual development scores. Scores obtained from further test results are recorded by the teacher to compare with previous results. Team scores are obtained by adding an increase in scores for all members in a team. The average value is obtained by dividing the number of added scores divided by the number of team members. 5) Team awards. The award is based on the average score of the team which can motivate them. 
To clarify the rationale for the use and application of STAD type cooperative learning in fourth grade students of SDN Kedungrejo, the following is the syntax of STAD type cooperative learning model:

\begin{tabular}{|c|c|}
\hline \multicolumn{2}{|r|}{$\begin{array}{l}\text { Learning Model Syntax } \\
\text { Cooperative STAD }\end{array}$} \\
\hline Phase & Teacher's Role \\
\hline 1. Teaching & The teacher presents lessons \\
\hline $\begin{array}{l}\text { 2. Learning } \\
\text { in teams }\end{array}$ & $\begin{array}{l}\text { Students working in their teams are guided by } \\
\text { student activity sheets to complete the subject } \\
\text { matter }\end{array}$ \\
\hline 3. Test & $\begin{array}{l}\text { Students do quizzes or other assignments } \\
\text { individually (e.g. essay or performance tests) }\end{array}$ \\
\hline $\begin{array}{ll}\text { 4. } & \text { Team } \\
\text { rewards }\end{array}$ & $\begin{array}{l}\text { Team scores are calculated based on team member } \\
\text { improvement scores, and certificates, class-scale } \\
\text { reports or notice boards to reward the team that } \\
\text { scored the highest score. }\end{array}$ \\
\hline
\end{tabular}

Source: Heri Purwanto (2011)

\section{METHODS}

The research used Class Action Research which consisted of two cycles. Each cycle includes planning, acting, observing and reflecting. For more details, see the PTK flow picture below:

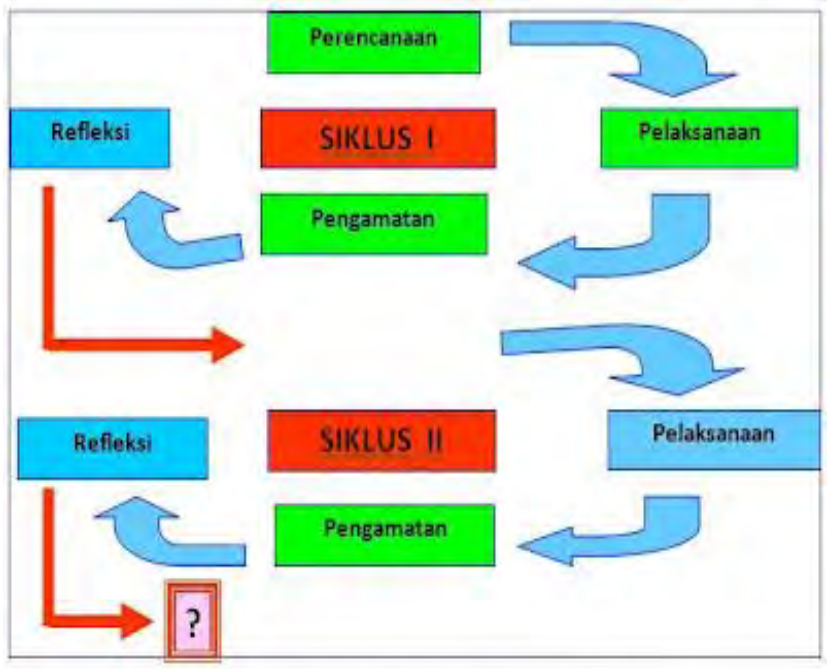

Tahap Penelitian Tindakan Kelas (Hopkins, 1993)

Figure 3.2. Flowchart of CAR

The procedure is in accordance with the type of Classroom Action Research, which consists of two cycles which include:

\section{a. Planning phase}

Based on the findings on the implementation of previous learning (Pre-cycle) the authors plan the steps of science learning in class by using the STAD Cooperative Learning
Model. Operationally the planning stage can be explained as follows:

1. Analyze the problem

2. Troubleshooting

3. Determine competency standards

4. Determine basic competencies

5. Determine indicators

6. Determine the purpose of improvement

7. Determine the material.

8. Determine the method.

9. Make an observation sheet.

\section{b. Implementation Phase}

At this stage, researchers carry out learning in accordance with the plans that have been formulated. Every step that has been planned is observed and collected data, both activity data during the learning process and learning outcomes data. This is intended to determine the increase in learning outcomes.

\section{c. Observation Stage}

Observation (Observation) is one of the data collection techniques or facts that are effective enough to study a system. In the observation phase (Observation) actually coincides with the implementation stage of the action, which is observing the learning process activities, and learning outcomes.

\section{d. Reflection Stage}

The results of observations carried out together with supervisor 2, then discussed. Various problems that arise during the implementation of the actions are identified and analyzed. The results of identification and problem analysis are sought and the solution is determined for improvement in the next cycle.

\section{Data Analysis Technique}

To collect data during research improvements, researchers used the following instruments:

\section{a. Observation sheet}

In simple terms, observation means observation with a specific purpose, namely to collect the results of improvement data.

Observations in classroom action research were carried out by the teacher as a researcher by supervisor 2, and observations of students as research subjects. Observation sheets for teachers as researchers are journals that have been provided by UT. Observation sheets for students as research improvement subjects are observations of student activities during the learning process, such as affective and psychomotor assessment sheets. 


\section{b. Test Sheet / Test Questions}

To find out the results of learning improvements, the data were collected through learning test results. The learning test is in the form of test questions arranged in the RPP (Learning Improvement Plan) of each cycle, precisely on the cognitive assessment sheet. Learning test results are included in a table, then described so that it is known to improve learning improvement in each cycle.

\section{RESULTS AND DISCUSSION}

The study was conducted to fourth grade students of SDN Kedungrejo Waru Sidoarjo in learning animal classification based on the type of food. Following are the results of evaluations carried out in the pre-cycle stage.

Of the 31 fourth grade students there are 10 students who get grades between $70-80$ is $32.2 \%$ (complete) while 21 students get grades between $40-60$ is $67.7 \%$ (incomplete). Completeness in the pre cycle only reached $32.2 \%$ and its incompleteness reached $67.7 \%$. From these results the researcher needs to conduct pre-cycle learning improvements carried out in cycle I.

\section{Cycle I}

After reflecting on the pre-cycle activities the author tries to make improvements to learning that starts from planning, implementing, observing and re-reflecting from the activity.

The researcher also held an assessment of the results of student evaluation which aims to determine the level of detention of students towards animal classification material based on the type of food. The results of the student evaluation with the following percentage of success: value $70-90=(20 / 31) * 100 \%=64.5 \%$ (Completed)

Value $50-60=(11 / 31) * 100 \%=35.5 \%($ Not Completed).

From the table of completeness of the student learning evaluation above, it can also be seen in the form of circle graphs as follows:

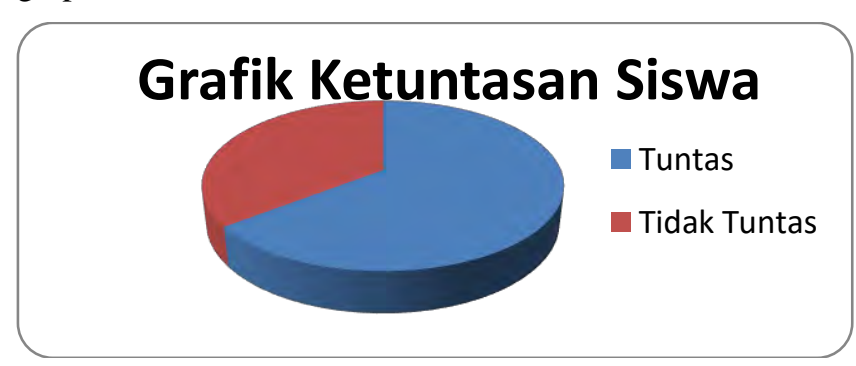

The completeness $64.5 \%$ according to the authors has not been satisfactory, so the authors feel the need to make improvements to learning cycle 2 .
Cycle II

Based on the results of the improvement in the first cycle the author made learning improvements in cycle II, by making planning, implementing, observing, and rereflection using the STAD Cooperative method. The results obtained from this cycle 2 improvement activity are as follows:

Value $=$ Amount correct $\mathrm{x} 10$

Percentage of success:

Value $70-100=(28 / 31) * 100 \%=90,3 \%$ (Completed)

Value $60=(3 / 31) * 100 \%=9.7 \%$ (Not Completed)

From completeness criteria table of student learning evaluation cycle II, it can also be seen in the form of circle graph as follows:

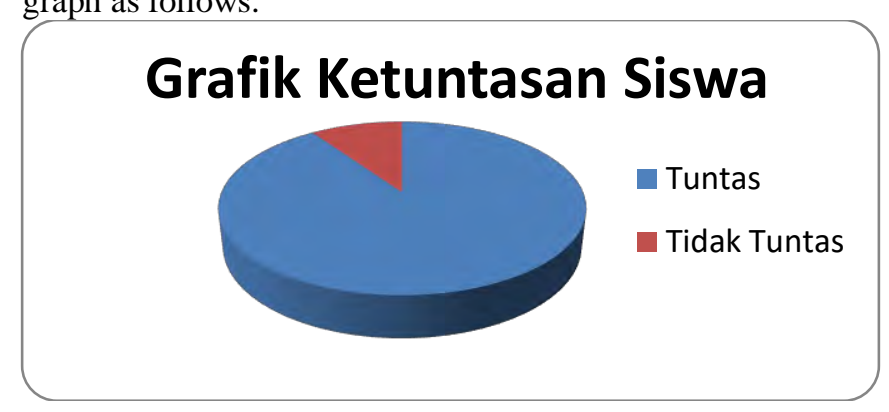

Based on the table and circle graph above, it can be seen that there are 3 students get 60 (10\%), 8 students get 70 (26\%), 12 students get 80 (39\%), 5 students get 90 (16\%), and 3 students get $100(10 \%)$. Based on these values students who have not completed are those who get a score of 60 there are 3 students $(9.7 \%)$ while students who are complete in learning are those who get grades between 70 100 which are 28 students $(90.3 \%)$. The results of completeness $90.3 \%$ according to the author is very satisfying, so the author feels no need to make improvements to learning again.

\section{Reflection}

The results of reflection in the second cycle have shown satisfying results, seen from students who get grades that meet the KKM reaching $90.3 \%$. This shows good results, in terms of subject matter, methods, and media used, time use, student involvement and class atmosphere. Thus, the next cycle is no longer needed and this condition must be maintained and improved again.

\section{CONCLUSION}

Based on the research conducted, the researchers concluded that the learning outcomes of the fourth grade students of SDN Kedungrejo in Waru Sub-district, Sidoarjo Regency in science learning, the material classification of animals based on the type of food with the STAD Cooperative method was very satisfying. The percentage of completeness was initially $32.3 \%$, then the first cycle was $64.5 \%$, and the second cycle reached $90.3 \%$. 
b. Follow-up advice

Teachers should help students construct knowledge from various information obtained and encourage students to actively involve in learning and motivate them to dare to express opinions, encourage students to solve problems based on their own abilities. Teachers should also be able to become facilitators and mediators in each teaching and learning activity, able to provide inputs and help students who experience difficulties and are able to apply appropriate methods in teaching that are able to have a good impact on learning outcomes.

\section{REFERENCES}

[1] Andayani, Dkk., (2009), Pemantapan Kemampuan Professional, Jakarta : Universitas Terbuka.

[2] Depdiknas., (2006), Kurikulum Tingkat Satuan Pendidikan Sekolah Dasar, Jakarta : Departemen Pendidikan Nasional.

[3] Hatimah, I., Sadri., (2008), Metode Penelitian, Jakarta : Universitas Terbuka.
[4] Nasution, N., dkk., (2007), Pendidikan IPA SD, Jakarta : Universitas Terbuka

[5] Nuryani Rustaman., (2010), Materi Dan Pembelajaran IPA SD, Jakarta : Universitas Terbuka.

[6] Sosiawan. Andi. (2009). Materi dan Pembelajaran IPA SD. Jakarta : Universitas Terbuka

[7] Wardani, I.G.A.K., Wihardit, K., (2008), Penelitian Tindakan Kelas, Jakarta : Universitas Terbuka.

[8] Wardani,I.G.A.K.,dkk., (2007), Tehnik Menulis Karya Ilmiah, Jakarta : Universitas Terbuka.

[9] Anita Lie. 2007. Cooperative Learning. Jakarta: Grasindo.

[10]Arifin, Zainal. 1991. Evaluasi Instruksional Prinsip-Teknik-Prosedur. Bandung: PT. Remaja Rosdakarya.

[11]Depdiknas. 2009. Model Silabus Sekolah Dasar Kelas IV (Bahasa Indonesia, Bahasa Inggris, PKn, PS, Matematika, IPA). Jakarta: Depdiknas.

[12]Ibrahim, Muslimin. 2000. Pembelajaran Kooperatif. Surabaya: University Press.

[13]Nasution, S. 2000. Didaktis Asas-Asas Mengajar. Jakarta : PT. Bumi Aksara.

[14]Slavin, Robert. 2009. Cooperative Learning (Teori, Riset dan Praktik). Cetakan ke-III. Bandung: Nusa Media.

[15]Purwanto, Heri. 2011. Pelatihan Pembuatan RPP Berkarakter. Sidoarjo: KKG 03 Waru. 